\title{
PENGETAHUAN DAN KETERAMPILAN IBU BEKERJA DALAM PEMBERIAN ASI EKSKLUSIF
}

\author{
Nikmatul Khayati ${ }^{1}$, Lusyana Nurhidayati ${ }^{2}$, Sri Rejeki ${ }^{3}$, Machmudah ${ }^{4}$ \\ Universitas Muhammadiyah Semarang \\ Email: nikmatul@unimus.ac.id
}

\begin{abstract}
ABSTRAK
Air susu ibu (ASI) merupakan makanan terbaik bagi bayi untuk membantu pertumbuhan dan perkembangan anak secara optimal serta melindungi terhadap penyakit. Cakupan ASI Eksklusif di Desa Bakung sebesar $67,8 \%$ dari harapan pemerintah sebesar $80 \%$. Ibu bekerja tetap dapat memberikan ASI Eksklusif pada bayi dengan cara pengelolaan ASI yang dapat diberikan saat ibu sedang bekerja. Penelitian ini bertujuan untuk mengetahui pengetahuan dan keterampilan ibu bekerja dalam pemberian ASI Eksklusif di Desa Bakung Mijen Demak. Metode penelitian ini menggunakan metode deskriptif teknik purposive sampling sebanyak 40 responden. Menggunakan instrument penelitian berupa kuesioner tertutup yang berisikan pengetahuan dan keterampilan ibu tentang ASI Eksklusif. Hasil dan kesimpulan penelitian ini menunjukan pengetahuan ibu bekerja sebanyak 67,5\% kategori baik dalam komponen waktu emerah, menyimpan serta mencairkan ASI dan keterampilan ibu bekerja sebanyak $45 \%$ kategori sedang dalam komponen memerah, menyimpan dan menyajikan ASI. Adanya pengetahuan dan keterampilan baik yang artinya ada kemampuan pengelolaan ASI menjadikan gizi bayi dapat terpenuhi. Saran untuk ibu tetap berupaya meningkatkan pengetahuan dan keterampilan dengan berbagai sumber literasi dari internet, tenaga medis, dan teman berbagi pengalaman serta dukungan kepada sesame ibu bekerja dalam mengelola ASI
\end{abstract}

Kata Kunci: ASI Eksklusif, Ibu Bekerja, Keterampilan, Pengetahuan

\begin{abstract}
Breastfeeding is the best food for babies to support optimal growth and development of children and protect against disease. Exclusive breastfeeding coverage in Bakung Village is $67.8 \%$ of the government's expectation of $80 \%$. Working mothers can still provide exclusive breastfeeding to babies by managing breast milk that can be given while the mother is working. This study aims to describe the knowledge and skills of working mothers in exclusive breastfeeding in Bakung Mijen Village, Demak. This research method uses a descriptive method of purposive sampling technique as many as 40 respondents. Using a research instrument in the form of a closed questionnaire containing knowledge and skills of mothers about exclusive breastfeeding. The results and conclusions of this study show an overview of the knowledge of working mothers as much as 67,5\% in the good category in the components of expressing, storing and serving breast milk. The existence of good knowledge and skills which means that there is an ability to manage breast milk and the skill of working mothers as much as $45 \%$ in the medium category in components expressing, storing and serving breast milk. The existence of good knowledge and skill which means that there is an ability to manage breast milk can make baby nutrition fulfilled. Suggestions for mothers to continue to improve their knowledge and skills with various literacy sources from the internet, medical
\end{abstract}


personnel, and friends to share experiences and support to fellow working mothers in managing breast milk.

Keywords : Exclusive Breastfeeding, Working Mothers, Skills, Knowledge

\section{PENDAHULUAN}

Pemberian ASI eksklusif yaitu dari bulan pertama atau sejak bayi dilahirkan sampai bulan keenam. Memberikan ASI murni pada bayi tanpa menambahkan berbagai macam cairan lainya kecuali obat-obatan tertentu atas anjuran petugas kesehatan dengan pertimbangan medis. Pemberian asupan ASI merupakan suatu perilaku yang sangat utama yang harus dilakukan ibu setelah melahirkan, sebagai penunjang pertumbuhan dan perkembangan bayi secara efektif dan optimal, baik fisik, mental serta kecerdasan. Maka sebab itu pemenuhan ASI harus mendapatkan perhatian yang lebih dari para ibu serta tenaga kesehatan demi tercapainya proses menyusui yang baik dan benar.

Pemerintah telah memberikan perhatiannya terhadap program pemberian ASI eksklusif dengan menetapkan kebijakan nasional yang dicantumkan dalam Peraturan Pemerintah Republik Indonesia Nomor: 33 Tahun 2012. Arah kebijakan dan rencana kesehatan masyarakat tahun 2020-2024 adalah target cakupan ASI eksklusif sebesar 66,02\% (Kementerian Kesehatan RI, 2020). Menurut data profil Kesehatan Jawa Tengah prosentase pemenuhan ASI eksklusif pada bayi 0-6 bulan di Provinsi Jawa Tengah pada tahun 2019 sebesar 66,0\% (Profil Kesehatan Provinsi Jawa Tengah, 2019). Data yang telah diperoleh dari profil Dinas Kesehatan Kabupaten/Kota Demak tahun 2019 cakupan pemberian ASI eksklusif di Kabupaten Demak sebanyak 65.0\%. Menurut data yang didapat dari Puskesmas Mijen I pada tahun 2020 pemberian ASI eksklusif pada bayi di Desa Bakung sebanyak 67,68\% (Profil Kesehatan Provinsi Jawa Tengah, 2019).

Air Susu Ibu (ASI) yaitu makanan paling baik bagi bayi yang mengandung berbagai komponen penting dalam tubuh seperti leukosit, protein, dan zat kekebalan lainya yang cocok untuk bayi. ASI mendukung pertumbuhan dan perkembangan anak secara optimal serta melindungi terhadap serangan penyakit. ASI mempunyai banyak manfaat diantaranya bagi bayi yaitu mengandung zat antibody yang berperan melindungi bayi terhadap penyakit, bagi ibu ASI dapat mencegah perdarahan pasca persalinan, mengurangi kejadian anemia dan ASI dapat menghemat biaya karena bayi yang sehat dapat menjadi salah satu factor penghemat pengeluaran keluarga karena tak perlu sering membawa bayi ke sarana kesehatan (Widyasari Dewi, 2019).

Ibu yang bekerja ataupun yang tidak bekerja hendaknya dapat memberikan ASI eksklusif sesuai dengan kebutuhan bayi. ASI merupakan sumber gizi utama bagi bayi, sehingga pengelolaan ASI dari mulai memerah, menyimpan sampai memberikan kepada bayi tentu saja ibu harus memahami agar pemberian ASI eksklusif bisa menjadi lancar. Kegagalan ASI eksklusif oleh para ibu yang pekerja seperti ditemukanya pendapat bahwa ASI tidak mencukupi, ibu kurang pengetahuan akan pentingnya ASI eksklusif walaupun ibu sedang bekerja yang mengakibatkan kurangnya waktu untuk memerah ASI, kurangnya keterampilan ibu dalam mengelola ASI, kurang memadainya fasilitas untuk menyusui dan memerah ASI. Maka pengelolaan ASI oleh ibu yang bekerja sangat penting untuk menunjang keberhasilan ibu supaya bisa memberikan ASI meski ibu sedang bekerja (Rahayu, 2018).

Dampak apabila bayi tidak diberikan ASI eksklusif bayi akan mengalami diare lebih sering, daya tahan tubuh bayi menurun, malnutrisi, terjangkit penyakit infeksi common 
cold, obstruksi usus karena pencernaan bayi belum sempurna (Nurraeni, 2018). Menurut data dalam penelitian (Dewi, 2020) 3 orang dari 10 ibu yang diwawancarai, hanya sebanyak 3 orang ibu yang telah melakukan pemberian asi secara eksklusif dan 7 ibu lainya memberikan susu formula secara dini. Beberapa hal tentang bahayanya susu formula, yakni peningkatan risiko alergi, peningkatan risiko asma, penurunan perkembangan kecerdasan bayi, meningkatkan risiko penyakit dengan gangguan pernafasan akut, infeksi, kegemukan, jantung, kencing manis, kekurangan gizi dan gangguan pertumbuhan (Dewi, 2020).

Bersumber pada latar beIakang yang telah diuraikan di atas, cakupan pemberian ASI eksklusif di desa bakung masih jauh dari angka harapan pemerintah sebesar $80 \%$. Mayoritas ibu di Desa Bakung bekerja sebagai karyawan swasta, banyaknya ibu yang kurang terpapar informasi mengenai pentingnya pemberian ASI eksklusif pada bayi. Ibu tidak perlu menghentikan pemberian ASI karena dapat mengelola ASI sebelum diberikan pada bayi. Sehingga peneliti tertarik untuk melakukan penelitian tentang pengetahuan dan keterampilan ibu bekerja dalam pemberian pemenuhan ASI.

\section{METODE}

Rancangan penelitian yang digunakan berupa deskriptif. Desain penelitian ini menggunakan desain cross sectional. Dalam penelitian ini peneliti melakukan penelitian tentang pengetahuan dan keterampilan ibu bekerja dalam pemberian ASI eksklusif di Desa Bakung Mijen Demak. Menggunakan instrument penelitian berupa kuesioner tertutup yang berisikan pengetahuan dan keterampilan tentang ASI eksklusif. Populasi dalam penelitian ini adalah seluruh ibu yang memiliki bayi umur 6-12 bulan sejumlah 40 orang. Teknik pengambilan sampel dalam penelitian adalah purposive sampling. Sampel pada penelitian ini adalah ibu yang bekerja di Desa Bakung Mijen Demak dengan kriteria inklusi yang bekerja, memiliki bayi berusia 6-12 bulan dan dengan tingkat Pendidikan SMP sampai Sarjana.

Instrument penelitian yang digunakan pada penelitian ini adalah kuesioner terdiri dari 25 pertanyaan dengan meliputi bagian: pengetahuan ibu tentang definisi ASI eksklusif, waktu memerah, penyimpanan dan mencairkan ASI. Bagian keterampilan meliputi bagian: memerah, menyimpan dan menyajikan ASI. Uji validitas pada instrument ini valid dengan nilai $r=0,361$ dengan tingkatan signifikan 5\%. Analisa data dilakukan dengan cara univariat hanya untuk mendeskripsikan.

\section{HASIL}

Berdasarkan penelitian yang dilakukan di Desa Bakung pada Juli 2021 dapat diketahui bahwa rata-rata usia ibu yang bekerja dengan usia termuda yaitu 21 tahun dan usia tertua yaitu 40 tahun dengan standar deviasi 4,957. Pendidikan ibu bekerja Sebagian besar adalah SMA sebanyak $17(42,5)$ dan Sebagian besar bekerja sebagai karyawan swasta dengan jumlah 15 orang $(37,5 \%)$.

Tabel 1 Distribusi frekuensi karakteristik responden berdasarkan usia, Pendidikan, dan pekerjaan ibu bekerja di Desa Bakung pada bulan Juli 2021 (n: 40)

\begin{tabular}{lllllll}
\hline $\begin{array}{l}\text { Karakteristik } \\
\text { Responden }\end{array}$ & $\begin{array}{c}\text { Freku } \\
\text { ensi } \\
\text { (f) }\end{array}$ & $\begin{array}{l}\text { Presentase } \\
(\%)\end{array}$ & Mean & SD & Min & Maks \\
& & & & & & \\
\hline Usia & & & 30,73 & 4,957 & 21 & 40 \\
\hline
\end{tabular}


Diagram 1 Frekuensi tingkat pendidikan responden

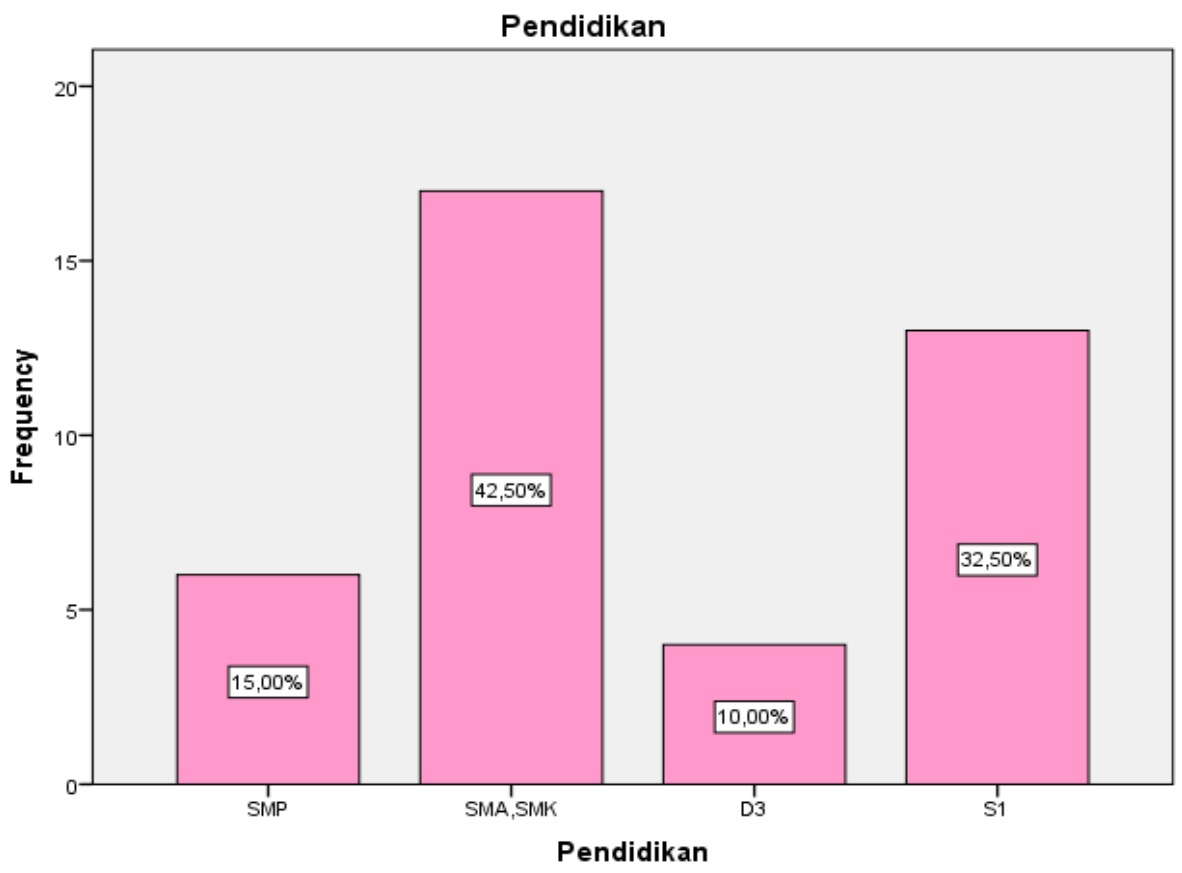

Diagram 1 Frekuensi tingkat pekerjaan responde

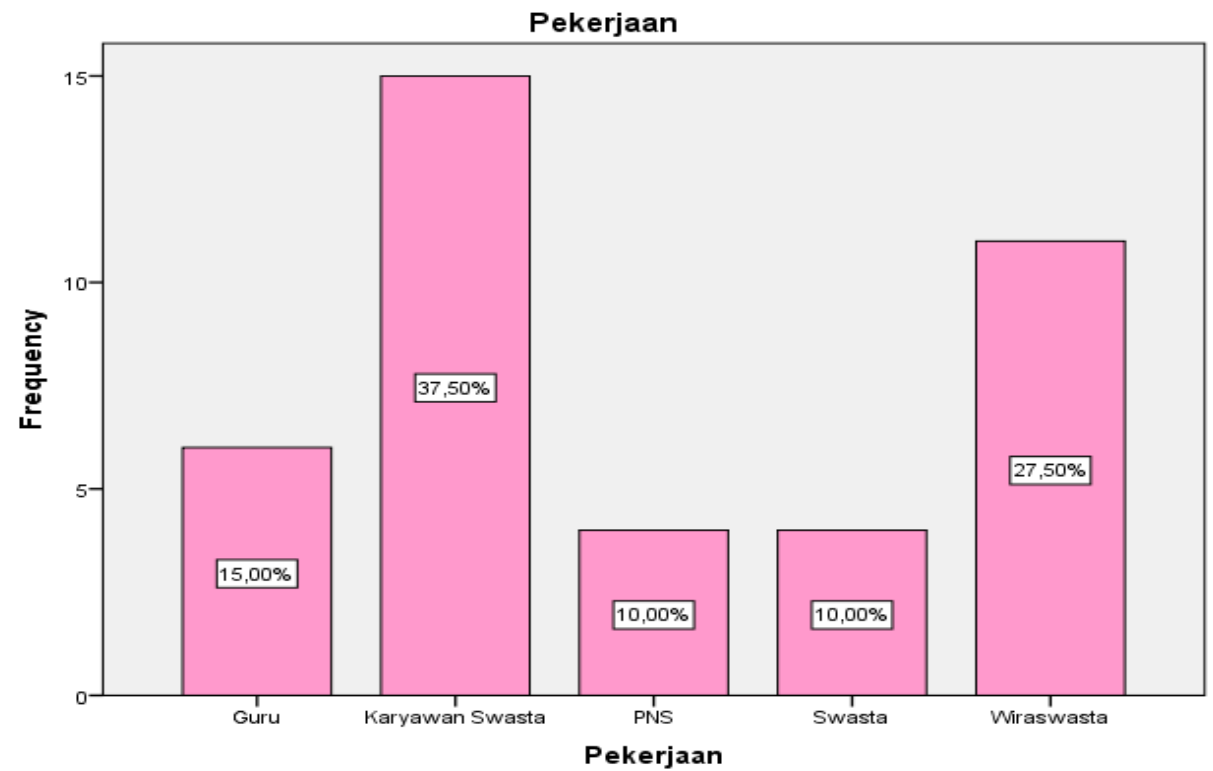




\begin{tabular}{lcc}
\hline Hasil Ukur Pengetahuan & Frekuensi & Presentase (\%) \\
\hline Baik & 27 & 67,5 \\
\hline Cukup & 8 & 20 \\
\hline Kurang & 5 & 12,5 \\
\hline Jumlah & 40 & 100 \\
\hline
\end{tabular}

Berdasarkan tabel 2 diatas dapat diketahui bahwa pengetahuan lbu bekerja tentang pemberian ASl EkskIusif pada bayi mayoritas pada kategori baik yaitu sebanyak 27 ibu (67,5\%), kategori cukup terdapat 8 responden (20\%) dan terdapat 5 responden yang temasuk dalam kategori pengetahuan kurang $(12,5 \%)$.

Tabel 3 Distribusi frekuensi jawaban keterampilan ibu bekerja di Desa Bakung

\begin{tabular}{lcc}
\hline Hasil Ukur Keterampilan & Frekuensi & Presentase (\%) \\
\hline Tinggi & 14 & 35 \\
\hline Hasil Ukur Keterampilan & Frekuensi & Presentase (\%) \\
\hline Sedang & 18 & 45 \\
\hline Rendah & 8 & 20 \\
\hline Jumlah & 40 & 100 \\
\hline
\end{tabular}

Berdasarkan TabeI 3 diatas dapat diketahui bahwa keterampilan ibu bekerja dalam pemberian ASI eksklusif pada bayi pada kategori sedang yaitu sebanyak 18 responden (45\%), kategori tinggi sebanyak 14 responden (35\%) dan kategori rendah sebanyak 8 responden $(20 \%)$.

\section{PEMBAHASAN}

Berdasarkan penelitian yang dilakukan di Desa Bakung pada Juli 2021 dapat diketahui bahwa rata-rata usia ibu yang bekerja dengan usia paling muda yaitu 21 tahun dan usia paling tua yaitu 40 tahun dengan standar deviasi 4,957 dengan usia termuda 21 tahun terdapat 1 responden termuda yang memiliki pengetahuan baik. HaI ini sejalan dengan penelitian yang dilakukan (Rohmah Nuswan Sari, 2017) yang menunjukan rentang usia produktif sebagian besar pada usia 20-35 tahun. Merupakan umur reproduksi sehat dan aman proses kehamilan, persalinan dan nifas serta cara mengasuh dan menyusui bayinya.

Hasil dari tingkat pendidikan, mayoritas responden pada penelitian ini berpendidikan SMA yakni sebanyak 17 responden $(42,5)$. Hal ini didukung oleh teori Notoadmodjo dalam (Dewi, 2017) bahwa tingkat pendidikan dapat mempengaruhi wawasan atau pengetahuan pada suatu idividu dimana pengetahuan yang lebih luas memiliki tingkat pendidikan yang tinggi dibandingkan dengan individu berpendidikan rendah, dengan demikian tingkat pendidikan yang cukup tinggi dapat mempengaruhi pembentukan kualitas padi diri individu dalam mengadopsi informasi atau hal baru seperti pentingnya pemberian ASl ekskIusif. Penelitian ini sejalan dengan (Istinganah, 2017) diterangkan bahwa ibu yang mendapatkan berbagai sumber informasi dan pengetahuan mengenai pola makan bayi yang baik memiliki latar belakang tingkat pendidikan tinggi. Sedangkan ibu dengan pendidikan yang lebih rendah memungkinkan ia lambat dalam mengadopsi pengetahuan baru, khususnya tentang haI-hal 
yang berhubungan dengan pola pemberian ASl.

Berdasarka pada karakteristik status pekerjaan responden mayoritas bekerja sebagai karyawan swasta sebanyak 15 responden (37,5\%). Sejalan dengan teori (Notoatmodjo, 2014) Apapun pekerjaan seseorang mampu membuat seseorang mempunyai pengetahuan dan pengalaman karena banyaknya kejadian yang dialami baik secara langsung maupun tidak langsung. Namun teori ini berbeda dengan penelitian (Agustini Hanifah, Astuti and Susanti Indra, 2017), bahwa ibu yang tidak bekerja pun tidak selalu memberikan ASl secara ekskIusif di sebabkan oleh berbagai hal seperti pengetahuan, air susu yang keluar sedikit dan faktor dukungan keluarga.

Pada penelitian ini didapatkan mayoritas pengetahuan responden memiliki pengetahuan baik sebanyak 27 responden $(67,5 \%)$ dan pengetahuan cukup sebanyak 8 responden $(20 \%)$. Hal ini didukung oleh faktor-faktor yang mempengaruhi pengetahuan seperti tingkat pendidikan, pekerjaan, usia, minat, pengalaman dan sumber informasi. Penelitian ini sejalan dengan (Rahayu, 2018) bahwa terdapat pendidikan seseorang cukup rendah memiliki pengetahuan yang cukup karena mereka memperoleh informasi dari keluarga, teman internet, majalah, koran dan tenaga kesehatan saat melahirkan. Pengetahuan tidak hanya didapatkan saat di bangku sekolah saja namun dapat dari berbagai sumber.

Pada penelitian ini didapatkan mayoritas keterampilan responden memiliki keterampilan sedang sebanyak 18 responden (45\%), minoritas keterampilan rendah sebanyak 8 resonden (20\%) dikarenakan ibu tidak memiliki keterampilan dalam mengelola ASI perah dengan faktor ASI tidak lancar dan langsung disusukan ke bayi. Keterampilan berarti cakap, mampu dan cekatan dalam melakukan sesuatu hal. Keterampilan memerlukan pelatihan, pengalaman serta kemampuan, karena pada dasarnya setiap individu memiliki kemampuan dasar yang berbeda-beda. Keterampilan dapat menghasilkan sesuatu yang lebih berharga serta cepat dan tepat (Iverson, 2010). Sejalan dengan hasil penelitian yang dilakukan (Rahayu, 2018) tentang gambaran pengetahuan keterampilan dan sikap ibu bekerja dalam pemberian ASI eksklusif di posyandu mawar sari antapani sebagian besar keterampilan ibu baik dalam mengelola ASI. Hal ini didukung oleh faktor-faktor yang mempengaruhi keterampilan secara langsung seperti motivasi, pengalaman dan keahlian (Widayatun, 2009) Ketiganya saling berhubungan membuat hasil keterampilan ibu bernilai sedang dengan adanya motivasi, pengalaman dan keahlian ibu dapat terampil dalam mengelola pemberian ASI secara eksklusif disaat mereka sedang bekerja.

\section{KESIMPULAN}

Berdasar pada hasil penelitian yang telah dilakukan dengan judul " Pengetahuan dan Keterampilan Ibu Bekerja dalam Pemberian ASI Eksklusif di Desa Bakung, Mijen, Demak" dapat disimpulkan:

1. Karakteristik berdasarkan usia ibu rata-rata 30,73 dengan usia termuda yaitu 21 tahun dengan standar deviasi 4,957. Pendidikan responden mayoritas tamatan SMA sebanyak $42,5 \%$, bekerja sebagai karyawan swasta $62,5 \%$ dan usia dewasa awal 62,5\%.

2. Pengetahuan pada ibu-ibu yang bekerja dalam pemberian pemenuhan ASI eksklusif di Desa Bakung Mijen Demak sebanyak 67,5\% dalam kategori baik.

3. Keterampilan ibu-ibu yang bekerja dalam pemberian pemenuhan ASI eksklusif di Desa Bakung Mijen Demak sebanyak 45\% dalam kategori sedang.

\section{SARAN}

1. Bagi masyarakat dan ibu bekerja

Diharapkan mempertahankan pengetahuan dan lebih meningkatkan keterampilan dalam mengelola ASI, membaca literasi dari berbagai sumber tenaga kesehatan dan 
internet sehingga bayi tetap bisa siberikan ASI secara eksklusif walaupun ibu sedang bekerja. Ibu yang memiliki keterampilan dalam mengelola ASI dapat membuat kelompok kecil untuk saling berbagi ilmu dan pengalaman.

2. Bagi Instansi Pendidikan

Hasil penelitian ini diharapkan dapat bermanfaat sebagai bahan bacaan atau dijadikan referensi untuk meningkatkan kualitas pendidikan keperawatan terutama tentang ASI eksklusif.

\section{DAFTAR PUSTAKA}

Agustini Hanifah, S., Astuti, S. and Susanti Indra, A. (2017) 'Gambaran karakteristik ibu menyusui tidak memberikan ASI eksklusif di Desa Cikeruh Kecamatan Jatinangor Kabupaten Sumedang tahun 2015'.

Dewi, F. S. (2017) 'faktor yang mempengaruhi pengetahuan seseorang menurut notoadmodjo'.

Dewi, S. dkk (2020) 'Kemajuan Teknologi Dalam Masyarakat, Promosi Susu Formula, Gaya Hidup, Dan Dukungan Tenaga Kesehatan Mempengaruhi Pemberian Susu Formula Pada Bayi Usia 0-6 Bulan', 3(4), pp. 317-325.

Istinganah, S. (2017) 'Gambaran karakteristik keberhasilan program ASI eksklusif pada ibu menyusui di puskesmas Turi Sleman'.

Iverson (2010) Memahami Keterampilan Pribadi. Bandung: CV Pustaka.

Kementerian Kesehatan RI (2020) 'Profil Kesehatan Indonesia Tahun 2019'.

Notoatmodjo, S. (2014) Ilmu Perilaku Kesehatan. 2nd edn. Jakarta: Rineka Cipta.

Nurraeni, H. (2018) 'Gambaran pengetahuan ibu menyusui yang mempunyai bayi 0-6 bulan tentang ASI eksklusif berdasarkan karakteristik di puskesmas kertasari kabupaten bandung tahun 2018'.

Profil Kesehatan Provinsi Jawa Tengah (2019) 'Profil Kesehatan Prov. Jateng Tahun 2019', Profil Kesehatan Jateng, 3511351(24), pp. 273-275.

Rahayu, D. (2018) 'Gambaran pengetahuan keterampilan dan sikap ibu pekerja dalam pemberian ASI eksklusif di posyandu mawar sari antapani'.

Rohmah Nuswan Sari, N. (2017) 'Gambaran karakteristik ibu dalam pemberian ASI di wilayah kerja puskesmas Girisubo, Kabupaten Gunungkidul'.

Widayatun (2009) Ilmu Perilaku. Jakarta: Info Medika.

Widyasari Dewi, F. (2019) 'Manajemen laktasi antara ibu pekerja dan ibu rumah tangga pada pemberian ASI eksklusif di wilayah kerja puskesmas sumbersari kabupaten jember'. 